\title{
Creating Students Loyalty Model in Private Higher Education
}

\author{
Muji Gunarto \\ Management Program Study, FEB, \\ Univeritas Bina Darma \\ Palembang-Indonesia \\ mgunarto@binadarma.ac.id
}

\author{
Lili Adi Wibowo \\ Management Program Study, \\ Universitas Pendidikan Indonesia \\ Bandung-Indonesia \\ liliadiwibowo@upi.edu
}

\author{
Ratih Hurriyati \\ Management Program Study, \\ Universitas Pendidikan Indonesia \\ Bandung-Indonesia \\ ratih@upi.edu
}

\begin{abstract}
Choosing a college is not as easy as choosing a product because the decision must consider the value of the future. However, there are some similarities in selecting universities, especially private universities. The purposes of this study to observe the factors that create student loyalty models and the loyalty of students at private colleges, so that the marketing managers of private universities are able to improve and maintain the students' effectiveness. The research is conducted on 5 private roommate colleges are selected randomly from the 27 private universities in Bandung, Indonesia. There are 250 respondents. The sampling technique is conducted by quota sampling on each of the private universities. The Data are analyzed by using structural equation modeling (SEM) and a data processing using AMOS program. Descriptively, the confidence of students in PHE relatively high, while loyalty, satisfaction and image of the PHE are very low. Results of student's loyalty building model from the three models offered, second model is the best model that can be used to explain the loyalty of students at PHE.
\end{abstract}

\section{Keywords - Student Loyalty, Trust, Higher-Education Image, Student Satisfaction}

\section{INTRODUCTION}

The competition of education services sector, especially among college Private Higher Education (PHE) in the fight over the "market" this student is quite heavy. Universities in Indonesia at this time flourished like mushrooms in the rainy season. The number of universities in Indonesia now has reached 3,193 which consists of 121 State Higher Education (SHE) and 3072 PHE by the number of students as much as $6,749,825$ ( $\mathrm{SHE}=2,224,718$ and $\mathrm{PHE}=4,525,107$ ) [1]. Until now SHE no shortage of students, but for the PHE should strive to get the student.

Nearly all private colleges feel the impact of great competition for students. This can be seen from the decline in the number of students in some private universities, especially at the undergraduate and diploma. The main factor that caused the decline in PHE students at the undergraduate level is for their diploma and non-regular (extention) opened by SHE around. Almost all the students still want to get into state universities with different preferences exist, but with the limitations of existing quotas on SHE, then only a small percentage of students who can enter. Results SBMPTN
(National Student Selection State University) in 2015 only 121 653 students $(17.5 \%)$ received from prospective students who enroll 693185 (www.sbmptn.or.id). This is an opportunity for PHE to get prospective students who are not accepted in state universities.

To make a purchase or selection of the college, the consumer can not be separated from the product characteristics such as the value of accreditation, quality of infrastructure. The second factor is the price (tuition) among oher is the first entrance fee and tuition fee per semester. Pricing by sellers will influence the buying behavior of consumers, because prices can be accessible by consumers will tend to make consumers make purchases of these products. The third factor is the location of where the college is located, because after a strategic and convenient location is an option for the student can choose the college. The next factor is the promotion, where there is a vigorous universities in promotion to get new students, but some are not doing promotion [2].

Preference's students enter SHE now is not in terms of price because the cost of education at state universities is almost equal to the cost of education in the PHE, but the selection of students at the college over the trust, the image of the college, quality of service and satisfaction. Although there are myths in selecting a college that is growing in some countries are different [3]. So the loyalty of students at state universities is relatively better than the PHE, however, does not mean loyalty student at PHE cannot be built. This becomes interesting because most students who study at PHE are those who are not accepted in state universities, so that loyalty is low. Several studies have been conducted in various countries associated with factors that influence student loyalty is satisfaction, the image of college, trust and quality of service [4] - [14].

The model of loyalty in the business industry has been done repeatedly but cannot be generalized in many cases and places [15]. Customer loyalty in the world of education is closely related to the loyalty of the students. Student loyalty is indispensable for the survival, and the timeline is going to a university. Student who have a high loyalty is an asset because it will give a positive recommendation and encourage friends, relatives or other people to use the services of education has 
suffered. In addition, they will return to the customer is possible to continue higher education in the College of proficiency level [16]. The final goal is the success of the institution can establish the relationships with its customers by establishing a strong customer loyalty [17].

Student's loyalty to a college becomes very important [18]. Student's loyalty research from several universities in Germany showed that the impact of service quality on loyalty is a doubling of commitments [4]. Student loyalty is determined by student satisfaction, student satisfaction which is determined by the perception of value is highly influenced by the image of the university, while the quality of services and infrastructure not determine the perception of value for students [9]. Satisfaction and affect the image of college student loyalty. Student satisfaction has a high association to the loyalty of students at three times the image of the college. While the image of the program of study the indirect effect on satisfaction with the image of college students [6]. Results of research on student loyalty PHE in the State of Sao Paulo, Brazil showed that $46 \%$ of the student loyalty can be influenced by the perception of quality, satisfaction, emotional commitment and confidence [12].

College as a service company certainly has the objective to maintain and increase the loyalty of its students through quality service, maintaining trust and improve the image of the college. Through the effective promotion may affect the image of the company and the satisfaction and loyalty [19]. Image is a major determinant of customer satisfaction and loyalty [20].

Loyalty student is a strategic competitive advantage because (1) search for new students certainly cheaper than maintaining existing ones, and (2) it is assumed that the loyalty of the students can pay after graduation, alumni continue to support academic institutions, not only by word of mouth but also through financial contributions to the institution and through job offers to new graduates [10]. Choosing a college is not as easy as selecting a product, because the decision must consider the value of the future. However, there are some similarities in choosing higher education, especially PHE. The students will form a set of preferences through some process and then will choose based on the level of interest. The low student's loyalty at PHE encourages university's management to conduct various strategic and tactical steps to attract new students while maintaining existing ones.

This study tries to test the loyalty of the model student at PHE. Several studies about the loyalty of the students had been done but the model has not been able used in general. The study [8], [20], [21] states that the image effect on satisfaction, but research [22] and [15] states that satisfaction influenced the image. While [23] states that satisfaction and image have a relationship and are the exogenous variables on attitudes and behavior. Imagery is also a moderating variable for the relationship between satisfaction and loyalty [24]. The study [25] it does not link the image with satisfaction in shaping the student loyalty. Image effects trust [15], [26]. Meanwhile, according to [10] of satisfaction can be boosted confidence. For this study a model built to test the loyalty of the students at the PHE of several models offered.

\section{LITERATURE REVIEW}

\section{A. Students Loyalty}

Customer loyalty as the mindset of a customer who holds a favorable attitude toward a company, commits to repurchase the company's products (or services), and recommends the products (or services) to others [27]. Customer loyalty is deefly held commitment to rebuy or repattonize a preferred product or service consistenly in the future, despite situational influences and marketing Efforts having the potential to cause switching behavior [28]. While [29] states that loyalty is defined as non-random purchase expressed over time by some decision making unit. Customer loyalty as customers who are satisfied with the products or services of the company and they become word of mouth advertisers are enthusiastic. He further expand the loyalty not only to the product or service, but also the entire portfolio of products and services of the company as part of a lifetime, or in other words, more brand loyalty [7].

Loyalty is a manifestation of the fundamental human needs to have, support, getting a sense of security and build engagement and creating emotional attachment [30], [31]. Behavior and customer loyalty is usually expressed with the repurchase, the intention of buying back and recommend to others and have a good relationship with the service provider [23]. Customer loyalty as the relative strength relationship between individual attitudes and repeat purchase mediated by social norms and situational factors [32].

Loyalty in education, especially in higher education is a positive commitment from the student to the educational services they experienced during their lectures [16]. There are several characteristics of loyal customers, namely 1) Make a purchase on a regular basis; 2) Buying outside the line of products/services; 3) Recommend other products; and 4) Shows the immunity of appeal similar products of competitors [29]. This means that customer loyalty is determined by: 1) Purchase repeated (repeat); 2) Rejection of competitors' products or are not influenced by the attractiveness of other services (retention) and 3) Make recommendations to others (referral).

\section{B. Customer Satisfaction}

The term "customer satisfaction" and "quality of service/services" are often used interchangeably for the same essence. Traditionally, the quality of service is defined as the difference between customer expectations regarding service and perceptions about the real services which it receives [33]. The consequences of such a concept is that it should be used to measure the satisfaction of two pairs of statements, namely to measure expectations and perceptions, making it impractical. Accordingly, various studies have shown that use only one of the components of satisfaction that have qualified so that in practice no longer use them [34].

Customer satisfaction can be regarded as a summary of the state of psychological or subjective judgments based on the customer experience compared to expectations [6]. Customer satisfaction is feeling happy or disappointed someone who emerged after comparing the performance (yield) of products 
or services who thought of the performance (results) is expected. Expectations formed from their past experiences and advice of friends or colleagues and appointments and information marketers and competitors [35], [36].

Satisfaction in the context of higher education institutions is not a stand-alone concept, satisfaction attributes associated with the services provided by the agency. The attributes itself commonly grouped into a number of dimensions (factors) are fewer. It was intended to simplify the attributes of a comparatively much. There are three common components that can be identified in the context of higher education institutions [37], namely: 1. Customer satisfaction is a response (emotional or cognitive); 2 . The response associated with a particular focus (expectations, product, consumption experience, and others); 3 . The response that occurs at a specific time (after consumption, after the selection, based on the accumulated experience, and others). As partners in higher education, the students hope to have a satisfying experience in the classroom with a valuable learning experience. So that the management in the classroom into something valuable for students, thus, faculty characteristics tend to be the main determinant of student satisfaction in higher education [38].

\section{Higher Education Image}

Perception is the process where in the individual select, organize and interpret stimuli into something meaningful [39]. Perception has a very important role in marketing. The image can not be printed like making the goods at the factory, but the image is the impression that is obtained in accordance with the person's knowledge and understanding about something [40]. Image formed of how the company carries out its operations, which has a major cornerstone in terms of services. Image shows the impression of an object to another object that is formed by processing information at any time from various reliable sources. So there are three important things in the image, namely: the impression of an object, the image formation process, and a reliable source. Object includes individuals and companies consisting of a group of people in it. The image can be formed by processing information that does not close the possibility of changes in the image of the object of their receipt of the information each time. The amount of trust objects to information resources provide the basis for acceptance or rejection of information. Sources of information can be derived from the company directly and or other parties indirectly [36].

Image or brand of a good company is a competitive advantage that affects the level of customer satisfaction. Feeling satisfied or not, consumers take place after having experience with the product and the company that initiated the purchase decision. Therefore we can conclude the existence of a good corporate image is important as internal resources to determine the corresponding object in the company. The image is formed based on impressions, based on the experiences of someone against something as consideration for a decision [40].

Higher education institutions have to maintain or develop a different image to create a competitive advantage in an increasingly competitive market [7]. The image of the college described as a single variable, namely the measurement of students' perception of the university/college. It is defined that the students' perceptions of the image of the university/college is the reputation or history and past actions are seen by the public [13].

Corporate image is a perception regarding a firm held in customers' memory and works as a filter, the which Affects the perception of the operation/activities run by the firm. Corporate image germinates as the customers Actively or passively receive and process information about a firm from various sources [15]. Generally, the customers keep an array of reflections embodied in mental or intellectual framework about a firm in their minds. Eventually corporate image influences customers' behavior or sometimes even their behavioral outcome (s) like-satisfaction, repurchase intention or recommending others about the firm or its products or services [15].

\section{Trust}

Trust is a confidence given to the other party in the relationship transaction based on a belief that people who believed they would fulfill its obligations as well as expected [41]. Factors that shape a person's belief against the other three, namely the ability, goodness (benevolence), and integrity. Capability refers to the competence and characteristics of the seller/ organization in influencing and authorize a specific region. In this case, how the seller is able to provide, to serve, to secure transaskis of interference of others. This means that consumers derive satisfaction guarantee and security of the seller in the transaction. Kindness is a seller's willingness to provide mutual satisfaction between himself and the consumer. Profits which the seller can be maximized, but also high customer satisfaction. Seller is not merely the pursuit of maximum profit alone, but also has a great interest in realizing customer satisfaction. Integrity is concerned with how the behavior or habit sellers in doing business. The information provided to consumers is completely inconsistent with the facts or not. The quality of the products sold are trustworthy or not [42].

Associated with the three-dimensional, it is explained that the abilities include competence, experience and institutional endorsement, and ability in science. Benevolence include attention, empathy, confidence, and acceptance. Integrity can be seen from the point of fairness, fulfillment, fidelity (loyalty), frankness (honestly), the linkage (dependability), and reliability [43].

Researchers had established that trust is essential for building and maintaining long-term relationships. Trust as the willingness of an exchange partner to rely on the other party in whom the former party has confidence [15]. Trust motivates the customers to continue their relationships with the service provider [44]

\section{E. Relations between research variables}

1) Relationship between Higher Education Image and Student Loyalty

Corporate image is positively linked with customer loyalty in three sectors namely, telecommunications, 
retailing and education [15]. [45] Also Mentioned that corporate image plays a significant role in fostering customer loyalty. The image of a good college student can increase loyalty [5] - [9], [13], [14]. Hence, following hypothesis has been proposed:

Hypothesis 1: Higher Education Image has a positive effect on student loyalty.

\section{2) Relationship between Customer Satisfaction and} Loyalty Student

Several authors Reported a positive link between customer satisfaction and customer loyalty. Numerous studies in the service sector have empirically validated also the positive relationship between satisfaction and behavioral intentions such as customer retention and positive word of mouth. Hart and Johnson (1999) mentioned that one of the vital prerequisites of genuine customer loyalty is total satisfaction [15]. High student satisfaction against a college student can increase loyalty [6], [8], [10], [12], [14], [17]. Hence, following hypothesis has been proposed:

Hypothesis 2: Customer satisfaction has a positive effect on student loyalty.

\section{3) Relationship between the Trust and Customer Loyalty}

Many researchers had reported that trust is fundamental in developing customer loyalty [15]. Public confidence is good against a college student can increase loyalty [13], [14], [43], [46] - [48]. Therefore, following hypothesis has been formulated:

Hypothesis 3: Trust has a positive effect on student loyalty.

\section{4) Relationship between Higher Education Image and Customer Satisfaction \\ According to Grönroos (1990) "(corporate) image is a} filter the which influences the perception of the operation of the company" [15]. Also He said that a favorable image of a firm should be considered an asset and it may influence customers' perception of quality and satisfaction. If the customers are satisfied, reviews their attitude toward the company is improved and improved eventually this attitude or impression will influence consumers' satisfaction [45]. Many researchers established that corporate image has a significant contributory role on developing customer satisfaction. The image of good colleges can increase student satisfaction [5] - [9], [13], [14]. Hence, the following hypothesis has been proposed:

Hypothesis 4: Higher Education Image has a positive effect on customer satisfaction.

5) Relationship between Trust and Customer Satisfaction In the higher educational researches, student's trust in the university can lead to student loyalty. Trust is a concept that, from the Researches, Affects all other constructs namely satisfaction relationship quality, value and commitment. The study by Elliott and Healy (2001) shows that student centeredness (or trust) have a strong impact on student satisfaction [13]. There are other also researches show that trust positively influences satisfaction [49]. Trust the good students to a college can increase student satisfaction. Hence, the following hypothesis has been proposed:

Hypothesis 5: Trust has a positive effect on customer satisfaction.

6) Relationship between Customer Satisfaction and Trust

Student's loyalty is influenced by the commitments, which affected the commitment Trust and confidence is affected student satisfaction [10]. Student satisfaction affects the trust and loyalty of students [14]. High student satisfaction can create a trust for customers or students. Hence, the following hypothesis has been proposed:

Hypothesis 6: Customer satisfaction has a positive effect on trust.

\section{7) Relationship between Higher-Education Image and Trust}

In the marketing literature, reputation or image of a firm is often linked with its credibility and trustworthiness as perceived by the customers. Numerous researchers have tried to explain the connection between reputation and corporate image with consumers' trust; especially in the context of student loyalty [13], [26]. Lin and Lu (2010) in their study presented evidence that corporate image has the strong positive impact on trust [15]. The researcher has hypothesized the following:

Hypothesis 7: Higher-education image has a positive effect on trust.

8) Relationship between Customer Satisfaction and Higher-Education Image

Corporate image is an outcome of the process related to a customer's experience or encounter with company. In that process, intangible ideas, thoughts or feelings growing niche to get congregated in customer's mind that eventually germinate into perceived corporate image. If the customer's encounter with the company generates satisfactory results, it would definitely help forming a positive impression about the company [15]. The level of satisfaction will be able to improve the image of higher education, the study also explains that the image becomes the mediation for the satisfaction and loyalty of students [6]. While addressing the consequence (s) of customer satisfaction the authors claimed that customer satisfaction boosted the reputation of the company considering the service environment [15]. Hence, the researcher has hypothesized the following:

Hypothesis 8: Customer satisfaction has a positive effect on Higher-Education Image.

\section{F. Conceptual Framework}

Based on the literature review three competing models on customer loyalty have been developed. Model (1) where satisfaction as an intervening variable for Image and Trust on student loyalty, as shown in Fig.1. Model (2) where the trust as an intervening variable for satisfaction and image of the student loyalty, as shown in Fig.2. Model (3) where image and 


\section{$\triangle$ ATLANTIS PRESS}

trust as an intervening variable for satisfaction to student loyalty, as shown in Fig.3. Considering the issue of same constructs and same indicators employed in all three models, these models can be called nested models [50]. However, the main objective of this study is evaluating these competing models.

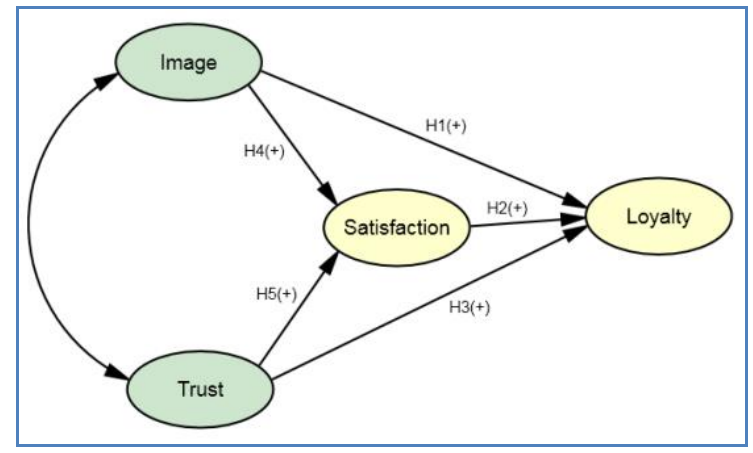

Fig. 1. Framework Model (1)

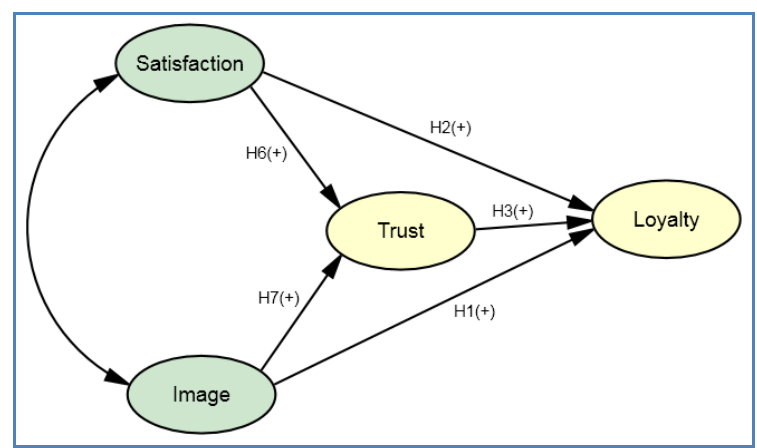

Fig. 2. Framework Model (2)

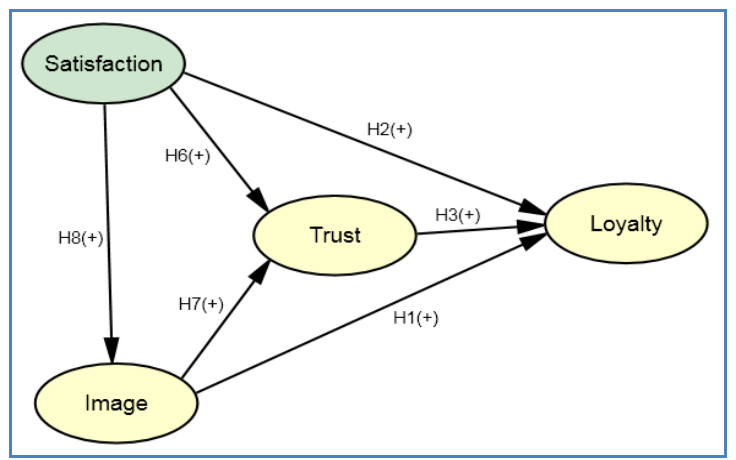

Fig. 3. Framework Model (3)

\section{RESEARCH METHODOLOGY}

Design of this research is descriptive and verification. The method used is survey by questionnaire as an instrument. This study was designed to analyze the influence of variables. Therefore, this study included an explanatory research, because trying to explain about the facts surrounding the studied variables, and verification because there was an attempt to test the hypothesis.

The study population was all students of Private Higher Education (PHE) in Bandung, Indonesia. The target population is the student who is at university in Bandung. PHE options in the form of the university for all the PHE has a postgraduate study program (S2 / S3). The sampling technique used was quota sampling of 250 respondents from five universities in Bandung, which was selected at random.

Instrument of this study using a questionnaire to measure variables Image, Trust, Satisfaction and Loyalty students by using a score of 7 (seven) [51]. Student loyalty variable adopted from [10], [14], [16], [21], [51], [52]. The image of the college adopted from [53], adopted from the student satisfaction [38], [51] and the Trust adopted from [18].

Data analysis was performed to present the research results and to test the hypothesis of the study. Data analysis technique used is the descriptive and inferential statistical analysis. Descriptive statistical analysis performed to present the data in simple research results are presented in the tabular form nor chart. Inferential statistical analysis was conducted to test the research hypothesis. Statistical analysis technique used is the approach Structural Equation Model (SEM). SEM is a statistical modeling technique that is most common and widely used in the science of behavior (behavior science). SEM can be shown as a combination of factor analysis, regression analysis and path analysis [54]. Data processing is done with the aid of the program package SPSS for Windows version 22 and AMOS Program Version 22.0.

\section{FINDINGS AND DISCUSSIONS}

\section{A. Descriptive Analysis}

Descriptive answers of 250 respondents in each of the variables shown in table 1 to table 4 . The standard score performance is $14.28 \%$ to $100 \%$ of the scale of $1-7$.

TABLE 1. DESCRIPTION OF RESPONDENTS ANSWERED TO TRUST VARIABLE.

\begin{tabular}{crrrrrrrrrr}
\hline Indicator & 1 & 2 & 3 & 4 & 5 & 6 & 7 & Score & $\begin{array}{c}\text { Value } \\
\max \end{array}$ & Results. \\
\hline TR1 & 14 & 36 & 15 & 48 & 48 & 50 & 39 & 1136 & 1750 & $64,91 \%$ \\
TR2 & 1 & 9 & 3 & 48 & 62 & 108 & 19 & 1311 & 1750 & $74,91 \%$ \\
TR3 & 2 & 0 & 3 & 47 & 67 & 107 & 24 & 1344 & 1750 & $76,80 \%$ \\
TR4 & 1 & 6 & 3 & 55 & 59 & 98 & 28 & 1321 & 1750 & $75,49 \%$ \\
Total & $\mathbf{1 8}$ & $\mathbf{5 1}$ & $\mathbf{2 4}$ & $\mathbf{1 9 8}$ & $\mathbf{2 3 6}$ & $\mathbf{3 6 3}$ & $\mathbf{1 1 0}$ & $\mathbf{5 1 1 2}$ & $\mathbf{7 0 0 0}$ & $\mathbf{7 3 , 0 3 \%}$ \\
\hline
\end{tabular}

Table 1 shows respondents' perceptions of the trust variable reached $73.03 \%$, this value indicates the confidence of respondents to the PHE is quite high. The lowest value occurs in the first indicator that says that the integrity of employees PHE, both administrative staff and faculty are still deemed less.

Table 2 shows respondents' perceptions of Higher Education Image variable only reaches $35.40 \%$, this value shows the image of respondents to the PHE is very low. This is quite natural because most students who study at PHE is a student who failed to be accepted in the SHE. The value of all the indicators of these variables was relatively similar to the lower image. 
TABLE 2. DESCRIPTION OF RESPONDENTS ANSWER TO HIGHER EDUCATION IMAGE VARIABLE.

\begin{tabular}{crrrrrrrrrr}
\hline Indicator & 1 & 2 & 3 & 4 & 5 & 6 & 7 & Score & $\begin{array}{c}\text { Value } \\
\max \end{array}$ & Results \\
\hline IM1 & 93 & 62 & 53 & 27 & 15 & 0 & 0 & 559 & 1750 & $31,94 \%$ \\
IM2 & 67 & 60 & 49 & 26 & 33 & 15 & 0 & 693 & 1750 & $39,60 \%$ \\
IM3 & 92 & 62 & 52 & 23 & 21 & 0 & 0 & 569 & 1750 & $32,51 \%$ \\
IM4 & 73 & 62 & 48 & 33 & 20 & 14 & 0 & 657 & 1750 & $37,54 \%$ \\
Total & $\mathbf{3 2 5}$ & $\mathbf{2 4 6}$ & $\mathbf{2 0 2}$ & $\mathbf{1 0 9}$ & $\mathbf{8 9}$ & $\mathbf{2 9}$ & $\mathbf{0}$ & $\mathbf{2 4 7 8}$ & $\mathbf{7 0 0 0}$ & $\mathbf{3 5 , 4 0 \%}$ \\
\hline
\end{tabular}

TABLE 3. DESCRIPTION OF RESPONDENTS ANSWER TO SATISFACTION VARIABLE.

\begin{tabular}{lrrrrrrrrrr}
\hline Indicator & 1 & 2 & 3 & 4 & 5 & 6 & 7 & Score & $\begin{array}{c}\text { Value } \\
\text { max }\end{array}$ & Results \\
\hline SAT1 & 4 & 24 & 42 & 79 & 64 & 24 & 13 & 1049 & 1750 & $59,94 \%$ \\
SAT2 & 5 & 25 & 38 & 87 & 48 & 36 & 11 & 1050 & 1750 & $60,00 \%$ \\
SAT3 & 30 & 48 & 68 & 61 & 31 & 12 & 0 & 801 & 1750 & $45,77 \%$ \\
SAT4 & 52 & 66 & 66 & 40 & 26 & 0 & 0 & 672 & 1750 & $38,40 \%$ \\
SAT5 & 5 & 26 & 70 & 46 & 44 & 36 & 23 & 1048 & 1750 & $59,89 \%$ \\
Total & $\mathbf{9 6}$ & $\mathbf{1 8 9}$ & $\mathbf{2 8 4}$ & $\mathbf{3 1 3}$ & $\mathbf{2 1 3}$ & $\mathbf{1 0 8}$ & $\mathbf{4 7}$ & $\mathbf{4 6 2 0}$ & $\mathbf{8 7 5 0}$ & $\mathbf{5 2 , 8 0 \%}$ \\
\hline
\end{tabular}

Table 3 shows respondents' perceptions of customer satisfaction variables only reached $52.80 \%$, this value indicates the satisfaction of respondents to PHE is still quite low. The lowest satisfaction levels occurred in all four indicators (SAT4), which is about the characteristics of a lecturer in PHE. While the highest satisfaction in this study achieved the 2nd indicator (SAT2) on their valuable experience during a lecture at PHE.

TABLE 4. DESCRIPTION OF RESPONDENT ANSWER TO STUDENT LOYALTY VARIABLE.

\begin{tabular}{crrrrrrrrrr}
\hline Indicator & 1 & 2 & 3 & 4 & 5 & 6 & 7 & Score & $\begin{array}{c}\text { Value } \\
\max \end{array}$ & Results \\
\hline LO1 & 7 & 10 & 32 & 107 & 94 & 0 & 0 & 1021 & 1750 & $58,34 \%$ \\
LO2 & 6 & 9 & 36 & 100 & 99 & 0 & 0 & 1027 & 1750 & $58,69 \%$ \\
LO3 & 9 & 37 & 109 & 41 & 54 & 0 & 0 & 844 & 1750 & $48,23 \%$ \\
LO4 & 13 & 29 & 87 & 89 & 32 & 0 & 0 & 848 & 1750 & $48,46 \%$ \\
Total & $\mathbf{3 5}$ & $\mathbf{8 5}$ & $\mathbf{2 6 4}$ & $\mathbf{3 3 7}$ & $\mathbf{2 7 9}$ & $\mathbf{0}$ & $\mathbf{0}$ & $\mathbf{3 7 4 0}$ & $\mathbf{7 0 0 0}$ & $\mathbf{5 3 , 4 3 \%}$ \\
\hline
\end{tabular}

Table 4 shows respondents' perceptions of student loyalty variables only reached $53.43 \%$, this value shows the loyalty of students to PHE is still quite low. The value of all the indicators on student loyalty variables relatively balanced.

\section{B. Confirmatory Factor Analysis (CFA)}

Validity and reliability in the measurement model used confirmatory factor analysis [50]. The model consists of four (4) latent variable with 17 indicators forming each variable. The results of modeling obtained measurement values Goodness of Fit statistics in Table 5.
TABLE 5. VALUES STATISTICAL GOODNESS OF FIT (GOF) MEASUREMENT MODEL.

\begin{tabular}{lllll}
\hline No & \multicolumn{1}{c}{$\begin{array}{c}\text { Criteria } \\
\text { GOF }\end{array}$} & $\begin{array}{c}\text { Cut- } \\
\text { off } \\
\text { value }\end{array}$ & Results & Conclusion \\
\hline & $\begin{array}{l}\mathrm{p} \text {-value of } \\
X^{2}=131,918\end{array}$ & $\geq 0,05$ & 0,108 & Fit \\
& df=113 & $\geq 0,90$ & 0,945 & Fit \\
2 & GFI & $\geq 0,90$ & 0,926 & Fit \\
3 & AGFI & $\geq 0,90$ & 0,989 & Fit \\
4 & CFI & $\leq 0,08$ & 0,026 & Fit \\
5 & RMSEA & & & \\
\hline
\end{tabular}

According to table 5. It is seen that all the statistical criteria of goodness of fit (GOF) that there is a good model meets the criteria (fit), so overall measurement models for each latent variable already matches the existing data. However, to see the validity and reliability of each variable be based on the value factor loading, construct reliability and variance extraction as shown in table 6.

TABLE 6. THE VALUE OF FACTORS LOADING, CONTRUCT RELIABILITI AND VARIANCE EXTRACTION IN EACH LATENT VARIABLE

\begin{tabular}{|c|c|c|c|c|c|}
\hline Indikator & Trus & Image & Satisfaction & Loyalty & Note \\
\hline TR1 & 0,385 & & & & Not valid \\
\hline TR2 & 0,773 & & & & Valid \\
\hline TR3 & 0,623 & & & & Valid \\
\hline TR4 & 0,588 & & & & Valid \\
\hline IM1 & & 0,756 & & & Valid \\
\hline IM2 & & 0,797 & & & Valid \\
\hline IM3 & & 0,827 & & & Valid \\
\hline IM4 & & 0,781 & & & Valid \\
\hline SAT1 & & & 0,723 & & Valid \\
\hline SAT2 & & & 0,729 & & Valid \\
\hline SAT3 & & & 0,706 & & Valid \\
\hline SAT4 & & & 0,701 & & Valid \\
\hline SAT5 & & & 0,600 & & Valid \\
\hline LO1 & & & & 0,819 & Valid \\
\hline $\mathrm{LO} 2$ & & & & 0,872 & Valid \\
\hline LO3 & & & & 0,789 & Valid \\
\hline LO4 & & & & 0,873 & Valid \\
\hline$C R$ & $\left.0,690^{*}\right)$ & 0,870 & 0,822 & 0,905 & $\left.{ }^{*}\right)$ Not \\
\hline$V E$ & $36,99 \%$ & $62,52 \%$ & $48,08 \%$ & $70,39 \%$ & Reliable \\
\hline $\begin{array}{c}C R \text { without } \\
\text { TR1 }\end{array}$ & 0,707 & 0,890 & 0,894 & 0,858 & \multirow{2}{*}{ Reliable } \\
\hline $\begin{array}{c}V E \text { without } \\
\text { TR1 }\end{array}$ & $44,99 \%$ & $62,52 \%$ & $48,08 \%$ & $70,39 \%$ & \\
\hline
\end{tabular}

Note: $C R=$ Construct Reliability $; V E=$ Variance Extraction

According to table 6 is seen that almost all values valid for a loading factor of more than 0.5 , except indicators TR 1 is less than 0.5 , so the indicator removed from the model [50]. Measurement model with 17 indicators to produce a latent variable (Trust) is not reliable because the value $\mathrm{CR}$ is smaller than 0.7 , so the indicator TR1 with a loading factor of less than 0.5 were excluded from the measurement model. A model said to be reliable if $\mathrm{CR}>0.7$ and $\mathrm{VE}>0.5$ [54]. Extraction variance value indicates how large the latent variables can explain variations in the data.

Variance and correlation matrix between variables trust, image, satisfaction and loyalty shown in Table 7. 
TABLE 7. THE VARIANCE AND CORRELATION MATRIX LATENT VARIABLE

\begin{tabular}{ccccc}
\hline & Trust & Image & Satisfaction & Loyalty \\
\hline Trust & $\mathbf{0 , 7 9 3}$ & & & \\
Image & 0,249 & $\mathbf{0 , 8 5 7}$ & & \\
Satisfaction & 0,225 & 0,103 & $\mathbf{0 , 9 2 3}$ & \\
Loyalty & 0,424 & 0,338 & 0,202 & $\mathbf{0 , 6 1 0}$ \\
\hline $\begin{array}{c}\text { Note: Square root values of AVE (Bold) are shown on the diagonal } \\
\text { while the other entries represent inter-construct correlations. }\end{array}$
\end{tabular}

According to Table 7. It is seen that variation of data in each variable are relatively homogeneous, whereas the correlation between the latent variables seen their low positive relationship between latent variables, except for the relationship between trust and loyalty shown moderate relations. This illustrates that the conditions that have relevance to the loyalty of students in PHE only trust they felt during the lecture.

\section{Analysis of Structural Equation Models (SEM)}

The result of the establishment of the three models with SEM parameter values is shown in Fig. 4 to Fig.6.

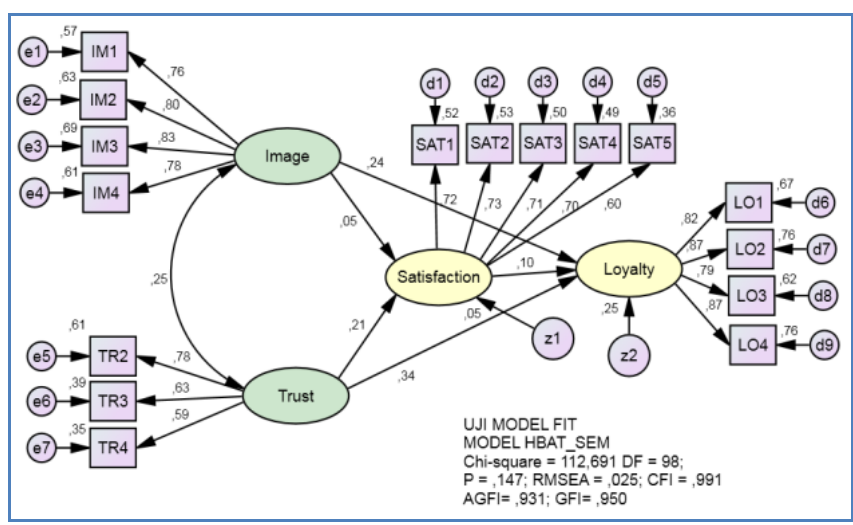

Fig. 4. Structural Model (1) with Standardized Estimates.

Model (1) shows that loyalty is directly influenced by the image of 0.24 , by satisfaction of 0.10 , and by the trust of 0.34 , but the statistics shows that only image and trust are significant $(p<0.05)$, while satisfaction significantly has no effect on loyalty (Fig.4)

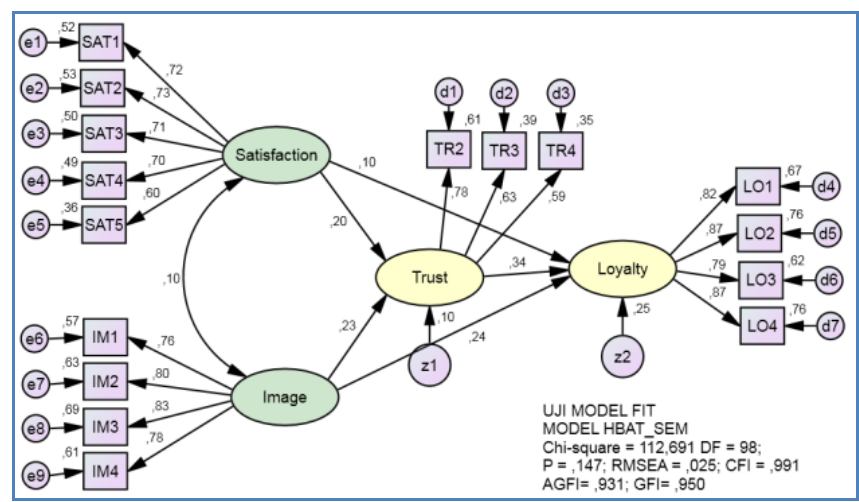

Fig. 5. Structural Model (2) with Standardized Estimates.
Model (1) also shows that satisfaction is influenced by the image of 0.05 and the trust of 0.21 , but the statistics shows that only trust influence to the satisfaction significantly $(\mathrm{P}<0.05)$ (Fig.4)

Model (2) shows that loyalty was influenced directly by satisfaction of 0.10 , by the trust of 0.34 and by the image of 0.24 , while statistics show only image and trust were significant $(\mathrm{p}<0.05)$, while satisfaction is not significantly influence to the loyalty (Fig.5).

Model (2) also shows that trust was influenced by the satisfaction of 0.20 and by the image of 0.23 . Statistics show, both are significant with almost the same large of influences (Fig.5).

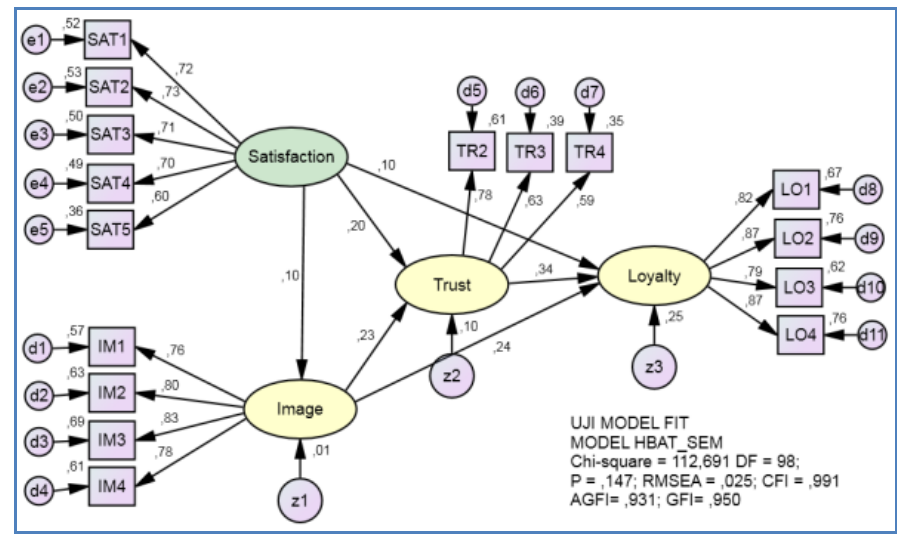

Fig. 6. Structural Model (3) with Standardized Estimates.

Model (3) shows that loyalty is directly affected by the satisfaction of 0.10 , by the trust of 0.34 and by the image of 0.24 , but statistics shows only image and trust were significant ( $\mathrm{p}<0.05$ ), whereas no significant effect on satisfaction to the loyalty (Fig.6).

Model (3) also shows that the trust is influenced by satisfaction of 0.20 and by the image of 0.23 , both statistically were significant $(p<0.05)$. Model (3) also test the image model, whether is influenced by the trust or not [6], [15], but the result shows that it was not significantly (Fig.6).

Test suitability models used several statistical value GOF, since the size of the suitability of a model is not a single [50], [54]. SEM model fit test results for all three models can be seen in Table 8.

TABLE 8. VALUES GOODNESS OF FIT THREE STRUCTURAL MODEL

\begin{tabular}{|c|c|c|c|c|c|c|}
\hline No & $\begin{array}{c}\text { Criteria } \\
\text { GOF }\end{array}$ & $\begin{array}{c}\text { Cut- } \\
\text { off } \\
\text { value }\end{array}$ & $\begin{array}{c}\text { Model } \\
\text { (1) }\end{array}$ & $\begin{array}{c}\text { Model } \\
\text { (2) }\end{array}$ & $\begin{array}{l}\text { Model } \\
\text { (3) }\end{array}$ & Conclusion \\
\hline 1 & $\begin{array}{l}\text { Significance } \\
X^{2}\end{array}$ & $\geq 0,05$ & 0,147 & 0,147 & 0,147 & Fit \\
\hline 2 & GFI & $\geq 0,90$ & 0,950 & 0,950 & 0,950 & Fit \\
\hline 3 & AGFI & $\geq 0,90$ & 0,931 & 0,931 & 0,931 & Fit \\
\hline 4 & CFI & $\geq 0,90$ & 0,991 & 0,991 & 0,991 & Fit \\
\hline 5 & RMSEA & $\leq 0,08$ & 0,025 & 0,025 & 0,025 & Fit \\
\hline
\end{tabular}


The third structural model provides statistical value GOF same and everything fit, meaning that the models created can explain variations in the data. Partial test results on each model is made to see the results of the research hypothesis testing. Testing the hypothesis for each model looks as shown in table 9.

Table 9 shows that the popularity of the eight (8) the hypothesis being tested is only 4 (four) the hypothesis that significant at the level of $5 \%$, while the three (3) other hypotheses are not significant, ie $\mathrm{H} 2, \mathrm{H} 4$ and $\mathrm{H} 8$. The hypothesis explains that the loyalty effect on student satisfaction (H2), which means that the level of satisfaction felt by students at PHE will not significant against loyalty. It is appropriate that the actual results on the ground in PHE student loyalty is still very low. Another hypothesis is not significant is the relationship between image and satisfaction (H4 and H8), this means that the student satisfaction in the PHE can not be built on the image of the university, and vice versa. Partially three models give similar results, but for the model (2) as compared to the model (1) or model (3) because there is only one hypothesis that is not significant from five hypotheses (80\%).

TABLE 9. HYPOTHESIS TEST RESULTS ON EACH MODEL

\begin{tabular}{|c|c|c|c|c|c|c|c|c|}
\hline Hipotesis & \multicolumn{3}{|c|}{ Model (1) } & \multirow{2}{*}{$\begin{array}{c}\text { Estimate } \\
0,205\end{array}$} & \multirow{2}{*}{$\begin{array}{c}\text { S.E. } \\
0,059\end{array}$} & \multirow{2}{*}{$\begin{array}{l}\text { C.R. } \\
3,483\end{array}$} & \multirow{2}{*}{$\frac{\text { P-Value }}{* * *}$} & \multirow{2}{*}{$\begin{array}{l}\text { Keterangan } \\
\text { Significant }\end{array}$} \\
\hline $\mathrm{H} 1$ & Loyalty & $<---$ & Image & & & & & \\
\hline $\mathrm{H} 2$ & Loyalty & $<---$ & Satisfaction & 0,081 & 0,057 & 1,431 & 0,153 & Not Significant \\
\hline $\mathrm{H} 3$ & Loyalty & $<---$ & Trust & 0,299 & 0,073 & 4,115 & $* * *$ & Significant \\
\hline $\mathrm{H} 4$ & Satisfaction & $<---$ & Image & 0,052 & 0,080 & 0,646 & 0,518 & Not Significant \\
\hline $\mathrm{H} 5$ & Satisfaction & $<---$ & Trust & 0,229 & 0,095 & 2,400 & 0,016 & Significant \\
\hline \multicolumn{9}{|c|}{ Model (2) } \\
\hline H1 & Loyalty & $<---$ & Image & 0,205 & 0,059 & 3,483 & $* * *$ & Significant \\
\hline $\mathrm{H} 2$ & Loyalty & $<--$ & Satisfaction & 0,081 & 0,057 & 1,431 & 0,153 & Not Significant \\
\hline $\mathrm{H} 3$ & Loyalty & $<---$ & Trust & 0,299 & 0,073 & 4,115 & $* * *$ & Significant \\
\hline H6 & Trust & $<---$ & Satisfaction & 0,186 & 0,075 & 2,496 & 0,013 & Significant \\
\hline $\mathrm{H} 7$ & Trust & $<---$ & Image & 0,220 & 0,077 & 2,858 & 0,004 & Significant \\
\hline \multicolumn{9}{|c|}{ Model (3) } \\
\hline $\mathrm{H} 1$ & Loyalty & $<---$ & Image & 0,205 & 0,059 & 3,483 & $* * *$ & Significant \\
\hline $\mathrm{H} 2$ & Loyalty & $<---$ & Satisfaction & 0,081 & 0,057 & 1,431 & 0,153 & Not Significant \\
\hline $\mathrm{H} 3$ & Loyalty & $<---$ & Trust & 0,299 & 0,073 & 4,115 & $* * *$ & Significant \\
\hline H6 & Trust & $<---$ & Satisfaction & 0,186 & 0,075 & 2,496 & 0,013 & Significant \\
\hline $\mathrm{H} 7$ & Trust & $<---$ & Image & 0,220 & 0,077 & 2,858 & 0,004 & Significant \\
\hline $\mathrm{H} 8$ & Image & $<--$ & Satisfaction & 0,099 & 0,073 & 1,366 & 0,172 & Not Significant \\
\hline
\end{tabular}

The results of this study also explains that the loyalty of the students in the PHE can be built on the trust of students [5] - [9], [13], [14] and image [5] - [9], [13], [14], where image significantly affect the trust [13], [15], [26], while student satisfaction can only be built on trust [4], [13] or vice versa [14]. The results of research that says that there is no influence satisfaction and loyalty of the student is not in line with previous studies such as [8], [12], [14], [17], [51], but this condition is possible because the descriptive level of student satisfaction in PHE is also very low.

\section{CONCLUSION \& SUGGESTIONS}

Descriptively, the confidence of students in PHE relatively high, while loyalty, satisfaction and image of the PHE are very low. Results of student's loyalty building model from the three models offered, second model is the best model that can be used to explain the loyalty of students at PHE, although there is a pattern of relationships that are not significant. However, based on the previous research, some researchers said that the satisfaction has an influence on loyalty. Partially, found that nearly all of the hypotheses are significant, except the relation of satisfaction and loyalty is not significant. It is more due to the characteristics of respondents consisting only of shaped PHE university. For that future studies are advised to conduct empirically loyalty of students at private universities in various forms and the wider region, and can add a variety of factors that can build student satisfaction at PHE.

\section{REFERENCES}

[1] Ristekdikti, "Naskah Akademik Klasifikasi dan Pemeringkatan Perguruan Tinggi Indonesia Tahun 2015," 2015.

[2] M. Gunarto and M. A. Syarif, "Penggunaan Analisis Biplot pada Pemetaan Perguruan Tinggi Swasta di Kota Palembang," Forum Manaj. Indones. 6, pp. 1-13, 2014.

[3] J. Knight, "Five Myths about Internationalisation," Int. High. Educ., no. 62, pp. 14-15, 2011.

[4] T. Hennig-Thurau, M. F. Langer, and U. Hansen, "Modeling and Managing Student Loyalty: An Approach Based on the Concept of Relationship Quality," J. Serv. Res., vol. 3, no. 4, pp. 331-344, 2001. 
[5] J. Hemsley-Brown and I. Oplatka, "Universities in a competitive global marketplace: A systematic review of the literature on higher education marketing," Int. J. Public Sect. Manag., vol. 19, no. 4, pp. 316-338, 2006.

[6] Ø. Helgesen and E. Nesset, "Images, Satisfaction and Antecedents: Drivers of Student Loyalty? A Case Study of a Norwegian University College," Corp. Reput. Rev., vol. 10, no. 1, pp. 38-59, 2007.

[7] H. Alves and M. Raposo, "the Influence of University Image in Student'S Expectations, Satisfaction and Loyalty," no. August, pp. 1-13, 2007.

[8] H. Alves and M. Raposo, "Conceptual Model of Student Satisfaction in Higher Education,” Total Qual. Manag., vol. 18, no. 5, pp. 571-588, 2007.

[9] R. M. Brown and T. Mazzarol, "Factors Driving Student Satisfaction and Loyalty in Australian Universities: The Importance of Institutional Image Factors Driving Student Satisfaction and Loyalty in Australian Universities: The Importance of Institutional Image," 20th Anпи. Aust. New Zel. Acad. Manag. Conf., pp. 1-12, 2006.

[10] J. I. Rojas-Méndez, A. Z. Vasquez-Parraga, A. Kara, and A. CerdaUrrutia, "Determinants of Student Loyalty in Higher Education: A Tested Relationship Approach in Latin America," Lat. Am. Bus. Rev., vol. 10, no. 1, pp. 21-39, 2009.

[11] S. Thomas, "What Drives Student Loyalty in Universities: An Empirical Model from India," Int. Bus. Res., vol. 4, no. 2, pp. 183-192, 2011.

[12] F. V. de M. Bergamo, A. C. Giuliani, S. H. C. R. V. de Camargo, F. Zambaldi, and M. C. Ponchio, "Student loyalty based on relationship quality: an analysis on higher education institutions," Brazilian Bus. Rev., vol. 9, no. 11, pp. 26-46, 2012.

[13] V. Taecharungroj, "University Student Loyalty Model: Structural Equation Modelling Of Student Loyalty in Autonomous, State, Transformed, and Private Universities in Bangkok," Scholar, vol. 6, no. 1, pp. 66-77, 2014.

[14] L. R. Aritonang R., "Student loyalty modeling," Trziste, vol. 26, no. 1, pp. 77-91, 2014.

[15] M. M. Akbar, "Three Competing Models on Customer Loyalty in the Context of Mobile Subscribers," Int. J. Mark. Stud., vol. 5, no. 4, pp. $42-58,2013$.

[16] S. E. Wahyuningsih, "Tingkat loyalitas mahasiswa atas jasa pendidikan di perguruan tinggi," Lembaran Ilmu Kependidikan, vol. 36, no. 2, pp. 131-137, 2007.

[17] M. Gunarto, "Strategi Membangun Kepuasan Konsumen dalam Rangka Membangun Loyalitas Pengunjung Objek Wisata Kota Pagaralam," Pariwisata dan Ekon., 2013.

[18] C. Y. Heo and S. Lee, "Examination of student loyalty in tourism and hospitality programs: A comparison between the United States and Hong Kong," J. Hosp. Leis. Sport Tour. Educ., vol. 18, pp. 69-80, 2016.

[19] M. Gunarto, "Pengaruh Bauran Promosi terhadap Citra Perusahaan dan Kepuasan Konsumen serta Implikasinya terhadap Loyalitas Pelanggan Minyak Pelumas Mobil di Kota Palembang," Kaji. Ekon. J. Penelit. Bid. Ekon., vol. 8, no. 1, pp. 1-16, 2009.

[20] C. Wu, "Destination loyalty modeling of the global tourism 2 , J. Bus. Res., 2015.

[21] R. M. Brown and T. W. Mazzarol, "The importance of institutional image to student satisfaction and loyalty within higher education," High. Educ., vol. 58, no. 1, pp. 81-95, 2009.

[22] Ø. Helgesen and E. Nesset, "What accounts for students' loyalty? Some field study evidence," Int. J. Educ. Manag., vol. 21, no. 2, 2007.

[23] R. A. Eliwa, "A Study of Customer Loyalty and the Image of the Fine Dining Restaurant," Oklahoma State University, 2006.

[24] M. W. Nyadzayo and S. Khajehzadeh, "The antecedents of customer loyalty: A moderated mediation model of customer relationship management quality and brand image," J. Retail. Consum. Serv., vol. 30, pp. 262-270, 2016.

[25] N. O. D. Arwanda, Hartoyo, and S. Hartoyo, "Kepuasan, Citra, dan Loyalitas pada Lembaga Pendidikan Tinggi: Kasus di Akademi XYZ," J. Ilmu Kel. dan Konsum., vol. 7, no. 2, pp. 123-132, 2014.
[26] A. Y. A. Fianto, D. Hadiwidjojo, S. Aisjiah, and Solimun, "The Influence of Brand Image on Purchase Behaviour Through Brand Trust," Bus. Manag. Strateg., vol. 5, no. 2, p. 58, 2014.

[27] S. Pearson, "Building brands directly: creating business value from customer Relationships," Macmillan Bus., vol. 20, no. 6, pp. 68-82, 1996.

[28] R. Oliver, "Whence consumer loyalty?," J. Mark., vol. 63, pp. 33-44, 1999.

[29] J. Griffin, Customer Loyalty: Menumbuhkan dan Mempertahankan Kesetiaan Pelanggan, Bhs Indoen. Jakarta: Penerbit Erlangga, 2005.

[30] R. Hurriyati, Bauran Pemasaran dan Loyalitas Konsumen. Bandung: Alfabeta, 2005.

[31] A. Buchari, Manajemen Pemasaran dan Pemasaran Jasa. Bandung: Alfabeta, 1992.

[32] A. S. Dick and K. Basu, "Customer Loyalty: Toward an Integrated Conceptual Framework," J. Acad. Mark. Sci., vol. 22, no. 2, pp. 99-113, 1994.

[33] A. Parasuraman, V. A. Zeithaml, and L. L. Berry, "SERQUAL: A Multiple-Item scale for Measuring Consumer Perceptions of Service Quality," Journal of Retailing, vol. 64. p. 28, 1988.

[34] P. A. Dabholkar, C. D. Shepherd, and D. I. Thorpe, "A comprehensive framework for service quality: an investigation of critical conceptual and measurement issues through a longitudinal study," J. Retail., vol. 76, no. 2, pp. 139-173, 2000.

[35] P. Kotler and K. L. Keller, Marketing Management. New Jersey: Prentice Hall, 2012.

[36] P. Kotler and G. Armstrong, Principles of Marketing, Fifteenth. England: Pearson Education Limited, 2014.

[37] A. A. Jahanshahi, G. M. A. Hajizadeh, S. A. Mirdhamadi, K. Nawaser and S. M. S. Khaksar, "Study the effects of customer service and product quality on customer satisfaction and loyalty.," vol. 1, no. 7, pp. 253-260, 2014.

[38] T. Gruber, A. Lowrie, G. H. Brodowsky, A. E. Reppel, R. Voss, and I. N. Chowdhury, "Investigating the Influence of Professor Characteristics on Student Satisfaction and Dissatisfaction A Comparative Study," $J$. Mark. Educ., vol. 34, no. 2, pp. 165-178, 2012.

[39] L. G. Schiffman, L. L. Kanuk, and H. Hansen, Consumer Behaviour: A European Outlook. 2012.

[40] A. Buchari and R. Hurriyati, Manajemen Corporate dan Strategi Pemasaran Jasa Pendidikan: Fokus Pada Mutu dan Layanan Prima. Bandung: Alfabeta, 2009.

[41] A. Rofiq, "Pengaruh Dimensi Kepercayaan (Trust) Terhadap Partisipasi Pelanggan E-Commerce," Universitas Brawijaya Malang, 2007.

[42] F. D. Schoorman, R. C. Mayer, and J. H. Davis, "An integrative model of organizational trust: Past, present, and future," Acad. Manag. Rev., vol. 32, no. 2, pp. 344-354, 2007.

[43] D. J. Kim, D. L. Ferrin, and H. R. Rao, "A trust-based consumer decision-making model in electronic commerce: The role of trust, perceived risk, and their antecedents," Decis. Support Syst., vol. 44, no. 2, pp. 544-564, 2008.

[44] N. Sharma and P. G. Patterson, "The impact of communication effectiveness and service quality on relationship commitment in consumer, professional services," J. Serv. Mark., vol. 13, no. 2, pp. 151170, 1999.

[45] T. W. Andreassen and B. Lindestad, "The Effect of Corporate Image in the Formation of Customer Loyalty," J. Serv. Res., vol. 1, no. 1, pp. 8292, 1998.

[46] O. Aygoren and C. Yilmaz, "Understanding Choice Behavior in Political Marketing Context: A Favorable Voter Responses Model," Dev. Mark. Sci. Proceeding Acad. Mark. Sci., pp. 274-281, 2013.

[47] R. Brennan and S. Hennenberg, "Does political marketing need the concept of customer value?," Mark. Intell. Plan., vol. 26, no. 6, pp. 559$572,2008$.

[48] C. Soong, Y. Kao, and S. Juang, "A Study on the Relationship between Brand Trust and the Customer Loyalty based on the Consumer Aspects," no. 2001, pp. 1-12, 2011. 
[49] T. Hennig-Thurau, M. F. Langer, and U. Hansen, "Modeling and Managing Student Loyalty: An Approach Based on the Concept of Relationship Quality,” J. Serv. Res., vol. 3, no. 4, pp. 331-344, 2001

[50] J. F. Hair, W. C. Black, B. J. Babin, and R. E. Anderson, Multivariate Data Analysis. Pearson Education Limited, 2014.

[51] G. R. Giner and A. Peralt Rillo, "Structural equation modeling of cocreation and its influence on the student's satisfaction and loyalty towards university," J. Comput. Appl. Math., vol. 291, pp. 257-263, 2016 .
[52] S. W. Carvalho and M. O. Mota, "The role of trust in creating value and student loyalty in relational exchanges between higher education institutions and their students," J. Mark. High. Educ., vol. 20, no. 1, pp. 145-165, 2010.

[53] V. Quintal and I. Phau, "Comparing student loyalty behavioural intentions across multi entry mode deliveries: An Australian perspective," Australas. Mark. J., pp. 1-11, 2016.

[54] M. Gunarto, Membangun Model Persamaan Struktural (SEM) dengan Program Lisrel. Palembang: Tunas Gemilang Press, 2013. 